\author{
BULETINUL INSTITUTULUI POLITEHNIC DIN IAŞI \\ Publicat de \\ Universitatea Tehnică „Gheorghe Asachi” din Iaşi \\ Volumul 67(71), Numărul 1, 2021 \\ Secţia \\ CONSTRUCTIII. ARHITECTURĂ \\ DOI: $10.2478 /$ bipca-2021-0002 \\ sciendo
}

\title{
STRESS-STRAIN RELATION LAWS FOR CONCRETE AND STEEL REINFORCEMENT USED IN NON-LINEAR STATIC ANALYTICAL STUDIES OF THE MOMENT RESISTING REINFORCED CONCRETE (RC) FRAME MODELS
}

BY

\section{ION SOCOCOL*, PETRU MIHAI, IONUTุ-OVIDIU TOMA, IOANA OLTEANU- DONT,OV and VASILE-MIRCEA VENGHIAC}

„Gheorghe Asachi” Technical University of Iasi,

Faculty of Civil Engineering and Building Services

Received: December 14, 2020

Accepted for publication: January 21, 2021

\begin{abstract}
Following the previous analytical studies performed with ATENA software for a series of RC moment resisting frame models, it were used in the pre-processing stage the stress-strain relation laws for concrete and steel reinforcement. These mathematical and graphical relations represent a necessity in the current conditions of numerical analysis and imply a correct knowledge of the deformation mode of the „reinforced concrete" which is a composite material. Thus, it is desired through this research paper the theoretical exposition of: equivalent uniaxial law for concrete, biaxial compressive failure and tensile failure consideration laws for concrete, bilinear with hardening law for steel reinforcement, cycling steel reinforcement model and steel reinforcement bond model. Finally, it will be possible to validate the correctness of the analytical RC frame systems through the experimental results of the optimal RC frame model after seismic platform testing.
\end{abstract}

Keywords: Stress-strain laws, concrete, steel reinforcement, ATENA software, RC frame system.

\footnotetext{
"Corresponding author; e-mail: ion.sococol@tuiasi.ro (C) 2021 Ion Sococol et al.

This is an open access article licensed under the Creative Commons Attribution-NonCommercialNoDerivatives 4.0 International License (CC BY-NC-ND 4.0).
} 


\section{Stress-Strain Relations for Concrete}

\subsection{Equivalent Uniaxial Law}

In analytical studies performed with ATENA software (Sococol et al., 2020 a), (Sococol et al., 2020 b), (Sococol et al., 2020 c), ,the nonlinear behavior of concrete in the biaxial stress state is described by means of the socalled effective stress $\sigma_{c}^{e f}$ and the equivalent uniaxial strain $\varepsilon^{e q}$ (Equation 1). The effective stress is in most cases a principal stress" (Cervenka et al., 2012), (Bi et al., 2020).

$$
\varepsilon^{e q}=\frac{\sigma_{c i}}{E_{c i}}
$$

„The complete equivalent uniaxial stress-strain diagram for concrete is represented in Fig. 1 and the material state number are used in the results of the nonlinear analysis to indicate the state of damage of concrete" (Cervenka et al., 2012), (Dong et al., 2021).

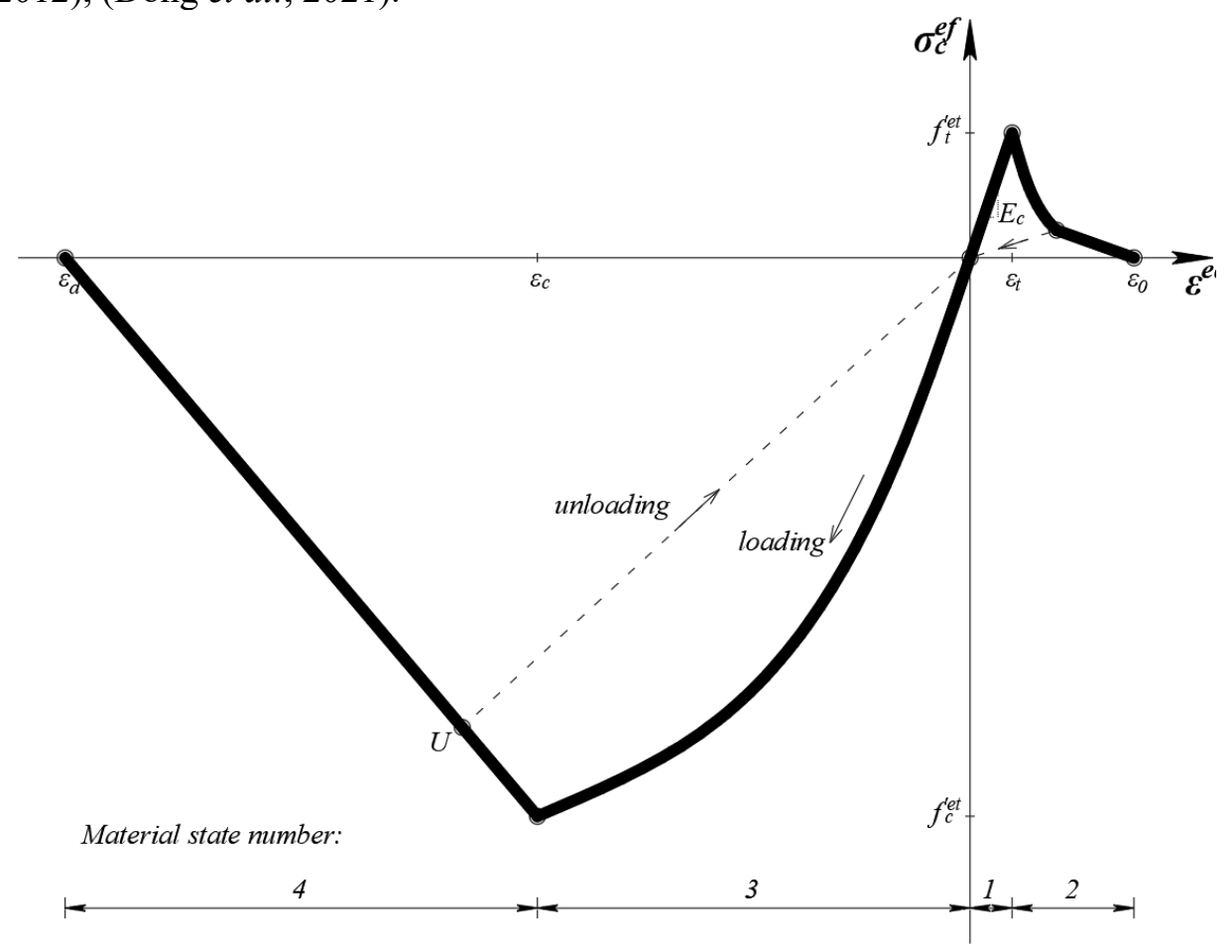

Fig. 1 - „Uniaxial stress-strain law for concrete” (Cervenka et al., 2012) 


\subsection{Biaxial Compressive Failure}

„A biaxial stress failure criterion according to Kupfer et al. (Kupfer et al., 1969 ) is used for consideration of concrete degradation of the moment resisting RC frame systems in analytical studies (Sococol et al., 2020 a), (Sococol et al., 2020 b), (Sococol et al., 2020 c) performed with ATENA software (see Fig. 2). In the compression-compression stress state, the failure function is" (Cervenka et al., 2012) (Equation 2):

$$
f_{c}^{\prime e f}=\frac{1+3.65 a}{(1+a)^{2}} \cdot f_{c, a}^{\prime}=\frac{\sigma_{c 1}}{\sigma_{c 2}}
$$

„where: $\sigma_{c 1}, \sigma_{c 2}$ are the principal stresses in concrete and $f_{c}$ is the uniaxial cylinder strength (Shiming \& Yupu, 2013), (Zhou et al., 2020). In the biaxial stress state, the strength of concrete is predicted under the assumption of a proportional stress path" (Cervenka et al., 2012).

"In the tension-compression state, the failure function continues linearly from the point $\sigma_{c 1}=0, \sigma_{c 2}=f_{c}$ into the tension-compression region with the linearly decreasing strength" (Cervenka et al., 2012) (Equation 3):

$$
f_{c}^{\prime e f}=f_{c}^{\prime} r_{e c}, \quad r_{e c}=\left(1+5.3278 \frac{\sigma_{c 1}}{f_{c}^{\prime}}\right), \quad 1.0 \geq r_{e c} \geq 0.9
$$

„where: $r_{e c}$ is the reduction factor of the compressive strength in the principal direction 2 due to the tensile stress in the principal direction 1" (Cervenka et al., 2012).

\subsection{Tensile Failure}

„In the tension-tension state, the tensile strength is constant and equal to the uniaxial tensile strength $f_{t}$. In the tension-compression state, the tensile strength is reduced by the relation" (Cervenka et al., 2012) (Equation 4):

$$
f_{t}^{\prime e f}=f_{t}^{\prime} r_{e t}
$$

„where: $r_{e t}$ (see Equation 5 and Equation 6) is the reduction factor of the tensile strength in the direction 1 due to the compressive stress in the direction 2 . The reduction function has one of the following forms (see Fig. 3)" (Cervenka et al., 2012). Also, ,mesh-size dependency and prediction of dynamic tensile failure are solved by nonlocal model", as specified in Xiangzhen et al. (Xiangzhen et al., 2019), (Xiangzhen et al., 2020). 


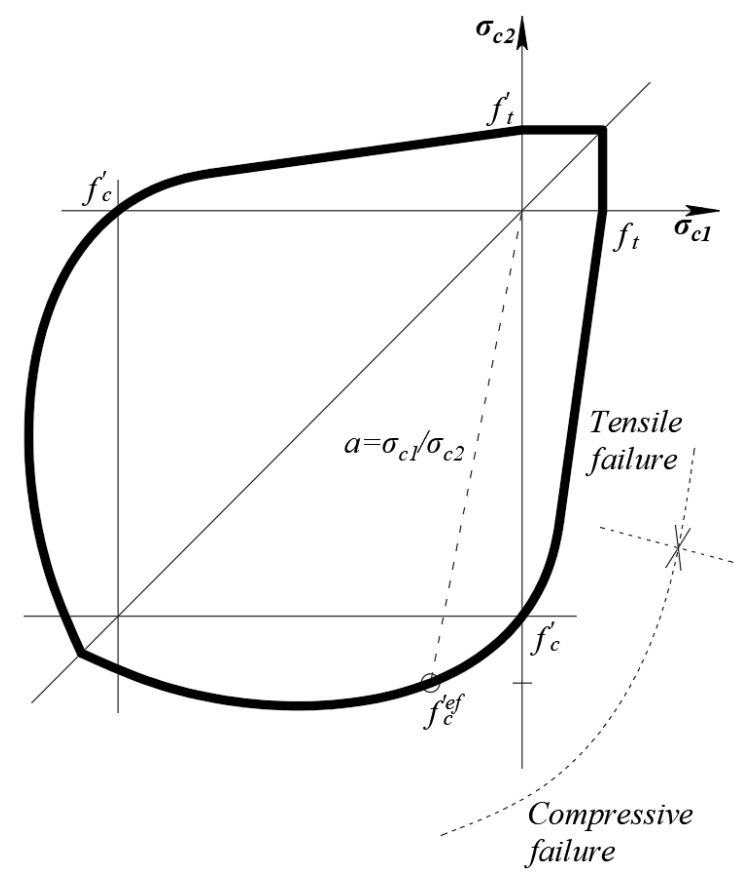

Fig. 2 - „Biaxial failure function for concrete” (Cervenka et al., 2012), (Kupfer et al., 1969) (see Table 1).

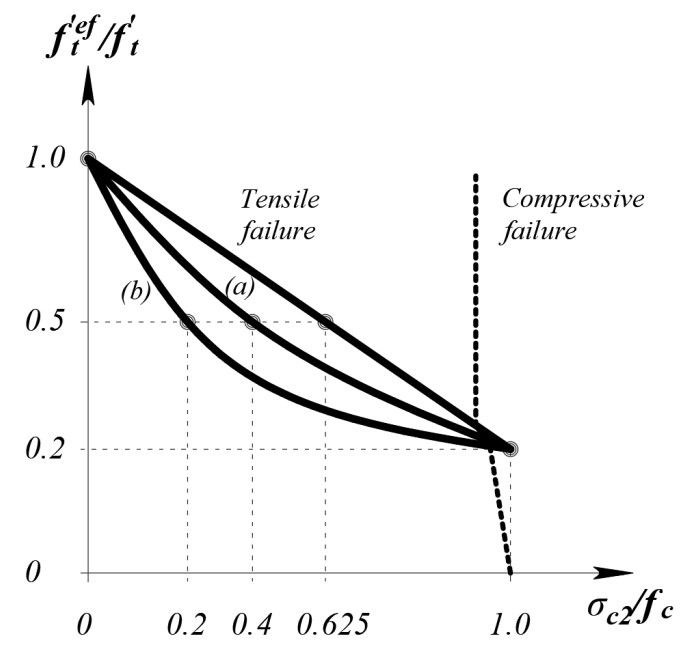

Fig. 3 - „Tension-compression failure function for concrete” (Cervenka et al., 2012) (see Table 1). 


$$
\begin{gathered}
r_{e t}=1-0.95 \frac{\sigma_{c 2}}{f_{c}^{\prime}} \\
r_{e t}=\frac{A+(A-1) B}{A B}, \quad B=K x+A, \quad x=\frac{\sigma_{c 2}}{f_{c}^{\prime}}
\end{gathered}
$$

„The relation in Equation 5 is the linear decrease of the tensile strength and Equation 6 is the hyperbolic decrease" (see Fig. 3) (Cervenka et al., 2012).

\section{Stress-Strain Laws for Steel Reinforcement}

\subsection{Bilinear with Hardening Law}

"The conventional stress-strain relationship of steel bar with a bilinear curve is widely used in numerical models because of its simplicity" (Wang et al., 2019). Thus, ,the bilinear with hardening law is accepted as shown in Fig. 4. The initial elastic part has the elastic modulus of steel reinforcement $E_{s}$. The second line represents the plasticity of the steel with hardening and its slope is the hardening modulus $E_{s h}$. Limit strain $\varepsilon_{\text {lim }}$ represents limited ductility of steel reinforcement" (Cervenka et al., 2012).

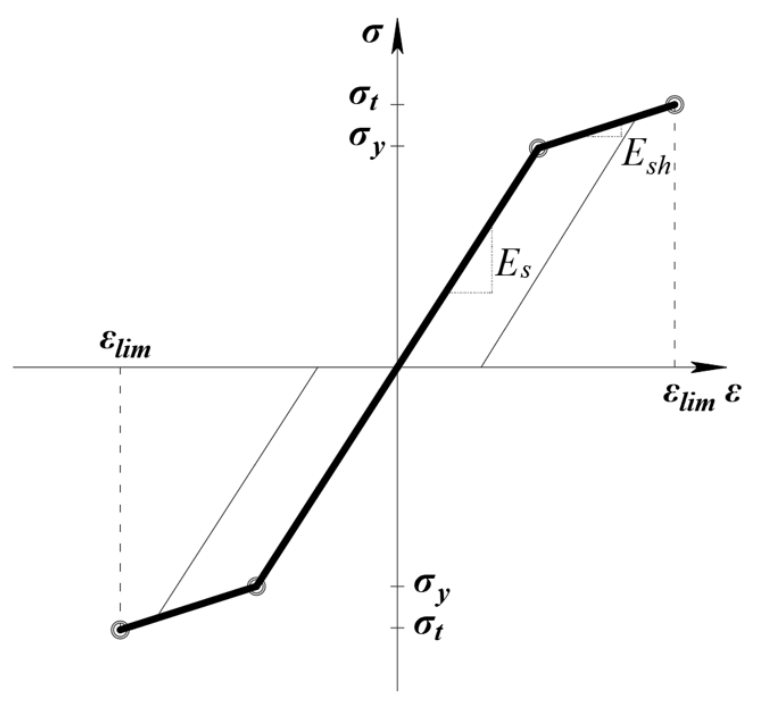

Fig. 4 - „The bilinear with hardening stress-strain law for Bst $500 \mathrm{~S}$ longitudinal reinforcement" (Cervenka et al., 2012), (ATENA software, 2015) (see Table 1). 
In these conditions, the longitudinal steel reinforcement deformation in the structure of the lateral elements ( $\mathrm{RC}$ beams and $\mathrm{RC}$ columns) of the moment resisting RC frame models it was considered in analytical studies performed with ATENA software (Sococol et al., 2020 a), (Sococol et al., 2020 b), (Sococol et al., $2020 \mathrm{c}$ ) according to bilinear with hardening stress-strain law (Fig. 4).

\subsection{Cycling Steel Reinforcement Model}

„To ensure the serviceability of reinforced concrete structures, deflection control is an important design objective. Excessive concrete cracking and excessive deformation are one of the most common causes of damage and result in large annual cost to the construction industry" (Xu et al., 2016). In these conditions, it is necessary to use a suitable cycling steel reinforcement model, to avoid these negative effects. In numerical analysis developed by Sococol et al. (Sococol et al., 2020 a), (Sococol et al., 2020 b), (Sococol et al., 2020 c) with ATENA software, ,the reinforcing steel stress-strain behavior is described by the nonlinear model of Menegotto and Pinto. Thus, in ATENA software, this model is extended to account of the isotropic hardening due to an arbitrary hardening law that can be specified for steel reinforcement. The stress in the cycling model is calculated according to the following expression (Equation 7)" (Cervenka et al., 2012):

$$
\sigma=\left(\sigma_{0}-\sigma_{r}\right) \sigma^{*}+\sigma_{r}
$$

where:

$$
\sigma^{*}=b \varepsilon^{*}+\frac{(1-b) \varepsilon^{*}}{\left(1+\varepsilon^{* R}\right)^{1 / R}}, \quad \varepsilon^{*}=\frac{\varepsilon-\varepsilon_{r}}{\varepsilon_{0}-\varepsilon_{r}}, \quad R=R_{0}-\frac{c_{1} \xi}{c_{2}+\xi}
$$

„where: $R_{0}, c_{1}$ and $c_{2}$ are experimentally determined parameters. The Fig. 5 shows the meaning of strain values $\varepsilon_{r}, \varepsilon_{0}, \xi$ and stress values $\sigma_{r}$ and $\sigma_{0}$. These values changes for each cycle. The values with the subscript , $r$ " indicate the point where the cycle started and the subscript „ 0 " indicates the theoretical yield point that would be reached during the unloading if the response would net have been modified by the hysteretic behavior. During the calculation of this point, the material stress-strain law is considered" (Cervenka et al., 2012) (Equation 9):

$$
\sigma^{*}=f_{R}\left(\varepsilon_{e q}\right), \quad \varepsilon_{e q}=\sum_{i=1}^{N_{\text {incr }}}\left|\Delta \varepsilon_{e q}^{i}\right|
$$




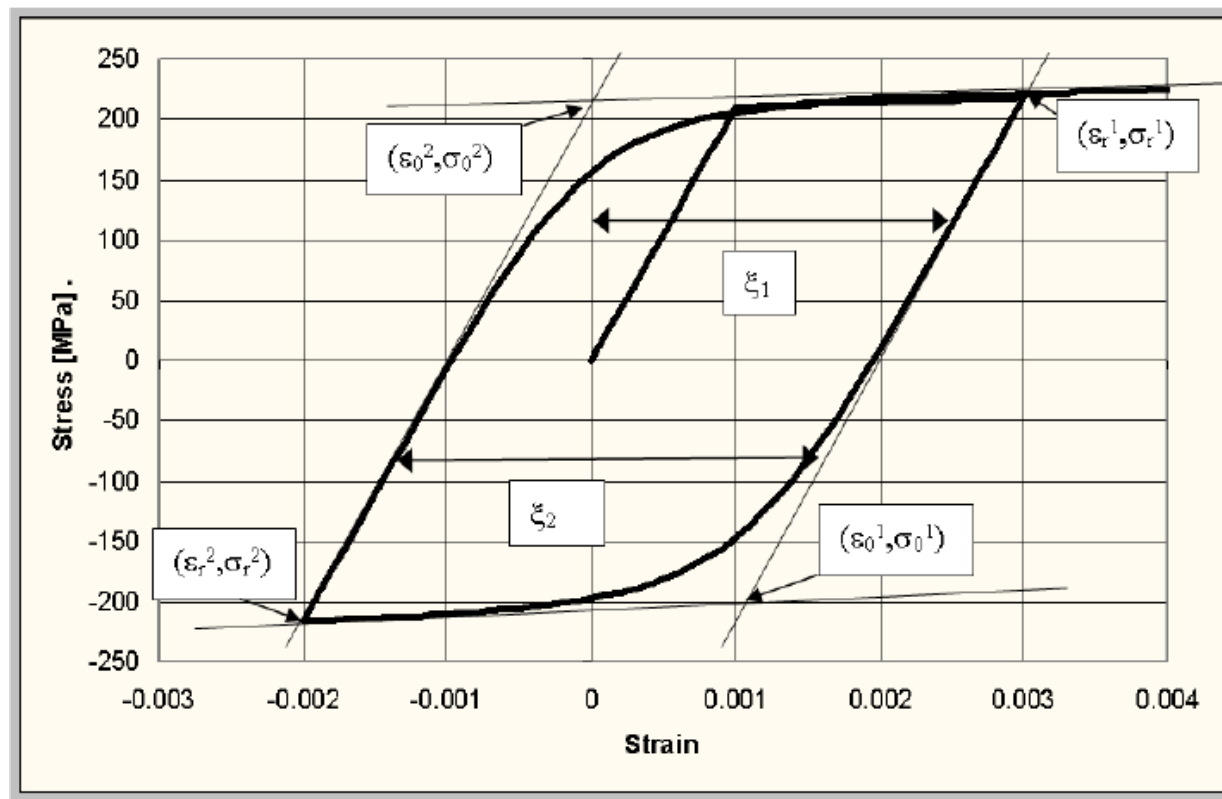

Fig. 5 - „Cycling steel reinforcement model based on Menegotto and Pinto” (Cervenka et al., 2012), (ATENA software, 2015).

Table 1

The mean values concrete strength and steel reinforcement strength used in nonlinear static analysis (ATENA software, 2015), (Cervenka et al., 2012) (see Fig. 1 -

Fig. 3 for concrete and Fig. 4 - Fig. 5 for longitudinal steel reinforcement)

\begin{tabular}{||c|c|c|c|c||}
\hline \hline Material name & $\begin{array}{c}\text { Elastic modulus } \\
\mathrm{E} \\
{[\mathrm{MPa}]}\end{array}$ & $\begin{array}{c}\text { Poisson's } \\
\text { ratio } \mu\end{array}$ & $\begin{array}{c}\text { Tensile } \\
\text { strength } \mathrm{f}_{\mathrm{t}} \\
{[\mathrm{MPa}]}\end{array}$ & $\begin{array}{c}\text { Compressive } \\
\text { strength } \mathrm{f}_{\mathrm{c}} \\
{[\mathrm{MPa}]}\end{array}$ \\
\hline \hline $\begin{array}{c}C 20 / 25 \\
\text { concrete } \\
\text { strength class }\end{array}$ & $3.000 E+04$ & 0.200 & $2.200 E+00$ & $-2.800 E+01$ \\
\hline
\end{tabular}

\begin{tabular}{||c|c|c|c|c|c||}
\hline $\begin{array}{c}\text { Material } \\
\text { name }\end{array}$ & Type & $\begin{array}{c}\text { Elastic } \\
\text { modulus E } \\
{[\mathrm{MPa}]}\end{array}$ & $\sigma_{\mathrm{y}}[\mathrm{MPa}]$ & $\sigma_{\mathrm{t}}[\mathrm{MPa}]$ & $\varepsilon \lim$ \\
\hline \hline Bst $500 \mathrm{~S}$ & $\begin{array}{c}\text { Bilinear } \\
\text { with } \\
\text { Hardening }\end{array}$ & $2.000 E+05$ & 575.000 & 632.500 & 0.060 \\
\hline
\end{tabular}




\subsection{Steel Reinforcement Bond Model}

"The basic property of the steel reinforcement bond model is the bondslip relationship. This relationship defines the bond strength (cohesion) $\tau_{b}$ (see Equation 10 - Equation 13) depending on the value of current slip between steel reinforcement and surrounding concrete" (Cervenka et al., 2012).

Also, ,bond stresses between steel reinforcement and concrete play a crucial role in ensuring reliable force transfer from the reinforcement to surrounding concrete" (Long et al., 2020), (Sabău, 2020). Thus, it was considered appropriate to use the bond-slip model according to CEB-FIP model code 1990 (CEB-FIP, 1990) (see Fig. 6) found in ATENA software (ATENA software, 2015) for the series of analytical studies regarding the consideration of the optimal RC frame experimental model performed by Sococol et al. (Sococol et al., 2020 a), (Sococol et al., 2020 b), (Sococol et al., 2020 c). In this case, ,the law is generated based on the concrete compressive strength, reinforcement diameter and reinforcement type. The important parameters are also the confinement conditions and the quality of concrete casting" (Cervenka et al., 2012).

The conditions for considering the transverse reinforcement mode of the structural elements in RC moment resisting frame models can be studied in research papers conducted by Sococol et al.

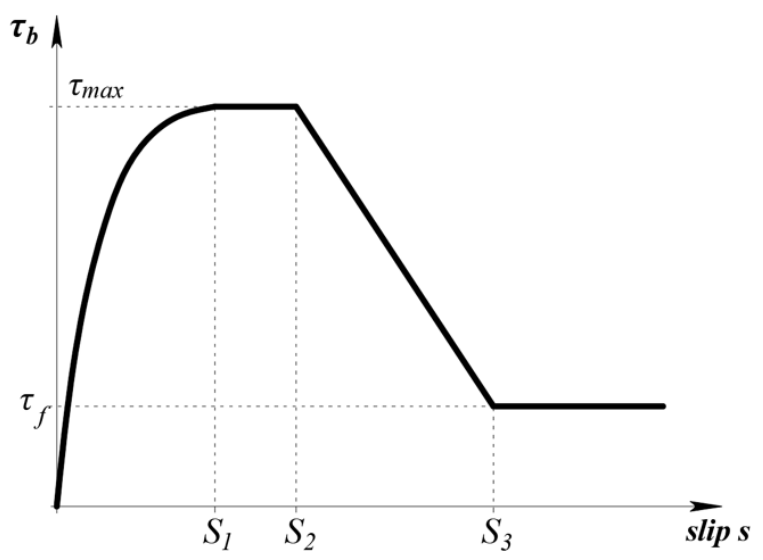

Fig. 6 - „Bond-slip law by CEB-FIP model code 1990” (CEB-FIP, 1990), (Cervenka et al., 2012), (ATENA software, 2015).

$$
\tau_{b}=\tau_{\max }\left(\frac{s}{s_{1}}\right)^{\alpha}, \quad 0 \leq s \leq s_{1}
$$




$$
\begin{gathered}
\tau_{b}=\tau_{\text {max }}, \quad s_{1}<s \leq s_{2} \\
\tau_{b}=\tau_{\max }-\left(\tau_{\max }-\tau_{f}\right)\left(\frac{s-s_{2}}{s_{3}-s_{2}}\right), \quad s_{2} \leq s \leq s_{3} \\
\tau_{b}=\tau_{f}, \quad s_{3}<s
\end{gathered}
$$

\section{Graphic Results of the Stress-Strain Laws for Concrete and Steel Reinforcement in ATENA software}

According to analytical studies conducted by Sococol et al. (Sococol et al., 2020 a), (Sococol et al., 2020 b), (Sococol et al., 2020 c) with ATENA software (ATENA software, 2015) considering stress-strain relations for concrete and steel reinforcement from current research paper, it can be graphically observed the cracking mode of K_5 RC frame model (see Fig. 7) (Sococol et al., $2020 \mathrm{c}$ ). The analytical results will superpose with the experimental results after seismic platform test of the optimal moment resisting RC frame model.

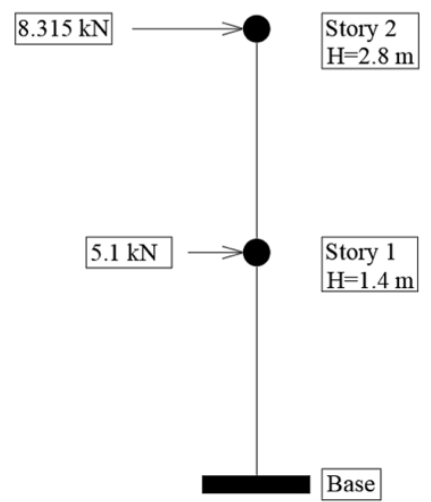

(a)

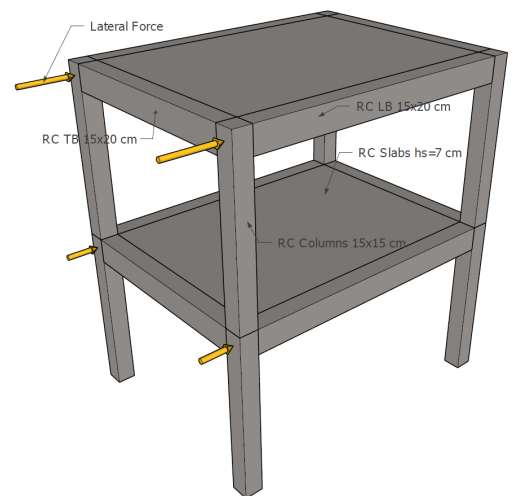

(b) 


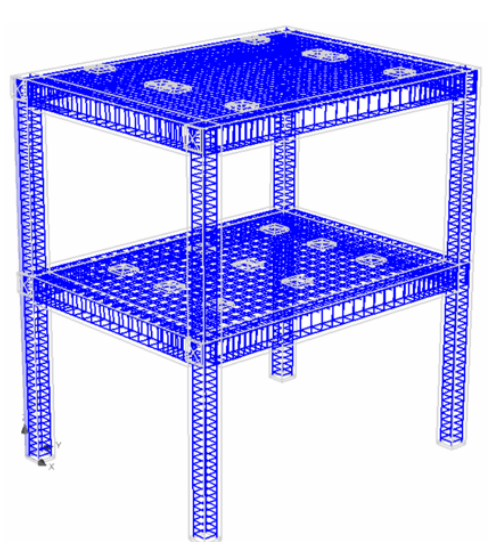

(c)

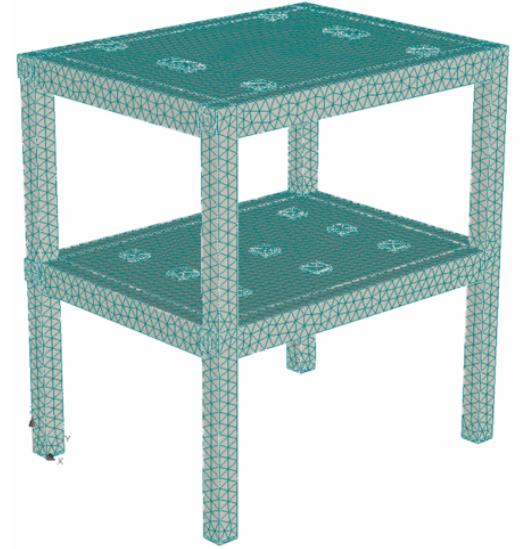

(e)

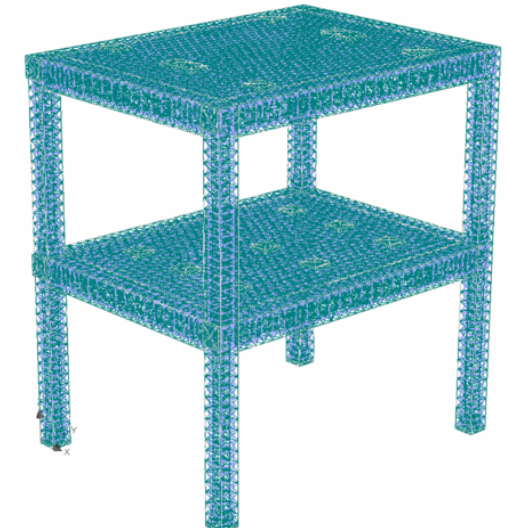

(d)

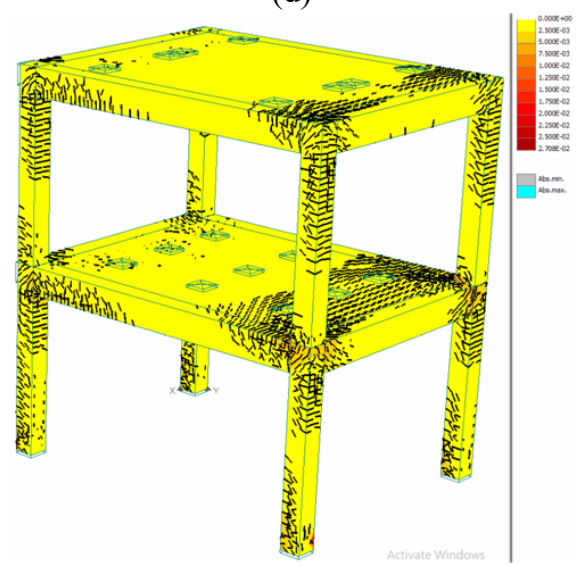

(f)

Fig. 7 - K_5 moment resisting RC frame system (Sococol et al., 2020 c): (a) „Representation of the discrete system with lateral load consideration in the longitudinal direction”; (b) „Pushover loading consideration”; (c) „Steel reinforcement carcase"; (d), (e) „Structural mesh discretization” (Bitencourt et al., 2018); (f) "Principal Fracture Strains Max (PFSM) representation".

\section{Conclusions}

The necessity for knowledge of stress-strain relation laws for concrete and steel reinforcement in analytical studies of the RC frame structures is highly important. The validation of the final results for numerical analysis are closely related to the correct consideration of stress-strain material laws.

In the case of the numerical studies specified in Sococol et al., ATENA software was used with stress-strain laws implementation in the chapters of this research article. 
Thus, in the final stage of experimental study, it will be verified the results obtained for the optimal RC moment resisting frame model (which will be tested on the seismic platform) with the existing analytical results.

\section{REFERENCES}

*** Cod de proiectare seismică", Partea I, Prevederi de proiectare pentru clădiri, Indicativ P100-1, Ministerul Dezvoltării Regionale și Administrației Publice, Mai 2013.

** CEB-FIP Model Code 1990, First Draft, Committee Euro-International du Beton, Bulletin d'information No. 195, 196, Mars.

$*^{*} *$ Eurocod 2: Proiectarea structurilor de beton, Partea 1-1: Reguli generale și reguli pentru clădiri, Indicativ SR EN 1992-1-1, ASRO, București, 2006.

ATENA software, http://www.cervenka.cz.

Bi J., Huo L., Zhao Y., Qiao H., Modified the smeared crack constitutive model of fiber reinforced concrete under uniaxial loading, Construction and Building Materials 250 (2020) 118916.

Bitencourt Jr. L.A.G., Manzoli O.L., Trindade Y.T., Rodrigues E.A., Dias-da-Costa D., Modeling reinforced concrete structures using coupling finite elements for discrete representation of reinforcements, Finite Elements in Analysis and Design 149 (2018) 32-44.

Cervenka V., Jendele L., Cervenka J., ATENA Program Documentation. Part 1. Theory, Prague, March 14, 2012.

Dong S., Wang Y., Ashour A., Han B., Ou J., Uniaxial compressive fatigue behavior of ultra-high performance concrete reinforced with super-fine stainless wires, International Journal of Fatigue 142 (2021) 105959.

Ivashenko Y., Ferder A., Experimental studies on the impacts of strain and loading modes on the formation of concrete "stress-strain" relations, Construction and Building Materials 209 (2019) 234-239.

Jokubaitis V., Juknevicius L., Salna R., Conditions for Failure of Normal Section in Flexural Reinforced Concrete Beams of Rectangular Cross-Section, $11^{\text {th }}$ International Conference on Modern Building Materials, Structures and Techniques, MBMST 2013, Procedia Engineering 57 (2013) 466-472.

Kupfer H., Hilsdorf H.K., Rusch H., Behavior of Concrete under Biaxial Stress, Journal ACI 66(8) (1969) 656-666.

Long X., Wang C-Y., Zhao P-Z., Kang S-B., Bond strength of steel reinforcement under different loading rates, Construction and Building Materials 238 (2020) 117749.

Sabău M., Simulated data on bond of steel reinforcement in self-compacting concrete, Data in Brief 30 (2020) 105594.

Saritas A., Filippou F., Numerical integration of a class of $3 d$ plastic-damage concrete models and condensation of $3 d$ stress-strain relations for use in beam finite elements, Engineering Structures 31 (2009) 2327-2336.

Shiming S., Yupu S., Dynamic biaxial tensile-compressive strength and failure criterion of plain concrete, Construction and Building Materials 40 (2013) 322-329.

Simao P.D., Barros H., Ferreira C.C., Marques T., Closed-form moment-curvature relations for reinforced concrete cross sections under bending moment and axial force, Engineering Structures 129 (2016) 67-80. 
Sococol I., Mihai P., Pruteanu M., Iftode V., Negative Influences (Effects) of Masonry Infilled RC Frames to Seismic Response of RC Frame Systems and Practical Methods (Solutions) for These Problems (State of the Art), Bulletin of the Polytechnic Institute of Jassy, Construction. Architecture Section 65 (4) (2019) 21-34.

Sococol I., Mihai P., Olteanu-Dontov I., Ductility - Concept for Improving the Seismic Response for Structural Reinforced Concrete Frame Systems, Bulletin of the Polytechnic Institute of Jassy, Construction. Architecture Section 65 (1) (2019) 17-30.

Sococol I., Mihai P., Iftode V.I., Olteanu-Dontov I., Study Regarding the Stiffness Influence of Slab to Beams for a Plan Structural Reinforced Concrete Frame System in Seismic Zones, Computational Civil Engineering Conference, CCE 2019, Iasi, Romania, May $30^{\text {th }}-31^{\text {th }}$, IOP Conference Series: Materials Science and Engineering 586 (2019).

Sococol I., Mihai P., Toma I.O., Venghiac V.M., Olteanu-Dontov I., Influence of Concrete Strength Class on the Plastic Hinges Location for a Reinforced Concrete Moment-Resisting Frame Structure with Consideration of the Horizontal Stiffening Effect of the Slab, Bulletin of the Polytechnic Institute of Jassy, Construction. Architecture Section 66 (2) (2020) 95-108.

Sococol I., Mihai P., Toma I.O., Venghiac V.M., Olteanu-Dontov I., Static Non-Linear Analysis of an RC Moment Resisting Frame by Considering Different Values for the Longitudinal Reinforcement Ratio in the Columns Bulletin of the Polytechnic Institute of Jassy, Construction. Architecture Section 66 (3) (2020) 91-106.

Sousa Jr. J.B.M., Muniz C.F.D.G., Analytical integration of cross section properties for numerical analysis of reinforced concrete, steel and composite frames, Engineering Structures 29 (2007) 618-625.

Wang Z-H., Li L., Zhang Y-X., Zheng S-S., Reinforcement model considering slip effect, Engineering Structures 198 (2019) 109493.

Wei H., Wu T., Liu X., Zhang R., Investigation of stress-strain relationship for confined lightweight aggregate concrete, Construction and Building Materials 256 (2020) 119432.

Xiangzhen K., Qin F., Jian H., A new damage-based nonlocal model for dynamic tensile failure of concrete material, International Journal of Impact Engineering 132 (2019) 103336.

Xiangzhen K., Qin F., Jinhua Z., Yadong Z., Numerical prediction of dynamic tensile failure in concrete by a corrected strain-rate dependent nonlocal material model, International Journal of Impact Engineering 137 (2020) 103445.

Xu T., Castel A., Gilbert R.I., Murray A., Modeling the tensile steel reinforcement strain in RC-beams subjected to cycles of loading and unloading, Engineering Structures 126 (2016) 92-105.

Zhou J., Pan J., Zhang L., Zhao J., Li Z., Experimental study on mechanical behavior of high-strength high-performance concrete under biaxial loading, Construction and Building Materials 258 (2020) 119681.

Zidonis I., Strength Calculation Method for Cross-Section of Reinforced Concrete Flexural Member Using Curvilinear Concrete Stress Diagram of EN-2, $11^{\text {th }}$ 
International Conference on Modern Building Materials, Structures and Techniques, MBMST 2013, Procedia Engineering 57 (2013) 1309-1318.

\author{
RELAȚIILE TENSIUNE-DEFORMAȚIE SPECIFICĂ PENTRU BETON ȘI \\ ARMĂTURĂ UTILIZATE ÎN STUDIILE ANALITICE STATICE NELINIARE A \\ MODELELOR SEISMO-REZISTENTE TIP CADRU DE BETON ARMAT
}

(Rezumat)

În urma calculului analitic efectuat cu programul ATENA pentru o serie de trame (modele) tip cadru de beton armat în studiile de cercetare anterioare, s-au utilizat în etapa de pre-procesare relații tensiune-deformație specifică corespunzătoare betonului și armăturii. Aceste relații cu reprezentare matematică și grafică reprezintă o necesitate în condițiile actuale de analiză numerică și implică o cunoaștere corectă a modului de deformare a materialului compozit „beton armat”. Astfel, prin prezenta lucrare de cercetare, se dorește expunerea teoretică a: equivalent uniaxial law for concrete, biaxial compressive failure and tensile failure consideration laws for concrete, bilinear with hardening law for steel reinforcement, cycling steel reinforcement model and steel reinforcement bond model. În final, prin intermediul rezultatelor experimentale a modelului optim tip cadru de beton armat ce urmează să fie încercat pe platforma seismică se va putea valida corectitudinea modelelor analitice. 